\title{
Sex ratio estimations of loggerhead marine turtle hatchlings by incubation duration and nest temperature at Sirte beaches (Libya)
}

\author{
IMED JRIBI $^{1}$, ABDELMAULA HAMZA $^{2}$, ALMOKTAR SAIED $^{2}$ and ATEF OUERGUI ${ }^{3}$ \\ ${ }^{1}$ Sfax Faculty of Sciences, University of Sfax, PO Box 1171, Sfax 3000, Tunisia. E-mail: imed.jribi@ fss.rnu.tn \\ ${ }_{2}^{2}$ Libyan Sea Turtle Program-Environment General Authority, PO Box 13793, Tripoli, Libya. \\ ${ }^{3}$ Regional Activity Centre for Specially Protected Areas, Yasser Arafat Boulevard, PO Box 337, \\ 1080 Tunis Cedex, Tunisia.
}

\begin{abstract}
SUMMARY: Hatchling sex ratios in loggerhead marine turtles (Caretta caretta) were estimated on the beaches near Sirte (Libya), using two methods: incubation duration and nest mean temperature during the middle third of the incubation period. Electronic temperature/humidity loggers were deployed at a total of 13 selected nests at Al-Ghbeba, Al-Thalateen, west of Al- Thalateen, Shash and Al-Arbaeen. The incubation period ranged from 47 to 58 days and average temperature ranged from $29^{\circ} \mathrm{C}$ to $31.8^{\circ} \mathrm{C}$. The maximum temperature during this period increased to between $0.6^{\circ} \mathrm{C}$ and $3.5^{\circ} \mathrm{C}$, while the mean temperature also increased during the middle third of the incubation period compared with the first third and continued to increase during the last third. As expected, this study showed that the temperature in the nest decreased with increasing depth of the nest. The results showed a female-dominated sex ratio at $85.4 \%$ on the basis of incubation duration and $70.4 \%$ on the basis of mean temperature. These findings support the reported highly female-skewed sex ratios in the Mediterranean and elsewhere.
\end{abstract}

Keywords: loggerhead turtle, hatchlings, sex ratio, incubation duration, nest temperature, Libya.

RESUMEN: ESTIMACIÓN DE LA PROPORCIÓN DE SEXOS DE CRÍAS DE TORTUGAS MARINAS CAGUAMA, MEDIANTE LA DURACIÓN DE INCUBACIÓN Y TEMPERATURA DE LOS NIDOS EN LAS PLAYAS DE SiRTE (LIBIA). - Se ha efectuado una estimación de proporción de sexos en las crías de tortugas marinas caguama (Caretta caretta) en las playas cerca de Sirte (Libia) utilizando dos métodos: la duración de la incubación y la temperatura media del nido durante el segundo tercio del período de incubación. Se registraron electrónicamente los valores de temperatura/humedad en un total de 13 nidos seleccionados en Al-Ghbeba, Al-Thalateen, zona oeste de Al-Thalateen, Shash y Al-Arbaeen. El período de incubación varió desde 47 hasta 58 días y la temperatura media osciló desde 29 hasta $31.8^{\circ} \mathrm{C}$. La temperatura máxima durante este período aumentó entre 0,6 y $3.5^{\circ} \mathrm{C}$, mientras que la temperatura media también aumentó durante el segundo tercio del período de incubación en comparación con el primer tercio y siguió aumentando durante el último tercio. Como era de esperar, este estudio mostró que la temperatura en el nido disminuyó con el aumento de la profundidad de la jerarquía. Los resultados basados en la duración de la incubación mostraron una sex-ratio en favor de las hembras del $85.4 \%$, mientras que este valor fue del $70.4 \%$ si los resultados se basaban en la temperatura media. Estos datos concuerdan con los estudios efectuados en el Mediterráneo y en otras zonas, en los que se aprecia una sex-ratio altamente sesgada en favor de las hembras.

Palabras clave: tortuga boba, crías, proporción de sexos, duración de la incubación, temperatura del nido, Libia.

\section{INTRODUCTION}

Marine turtles (family Cheloniidae) are an example of a species that is diminishing in numbers as a result of the degradation of the living and nesting habitats, incidental catches, and pollution (Lutcavage et al. 1997).
Significant resources are currently devoted to numerous conservation and management projects at nesting areas. One of most important and costly activities in management projects is the monitoring of beaches to protect nests and hatchlings from anthropogenic threats, such as coastal development, sand extraction 
and tourism, in addition to management of natural predation, to ensure high hatching success (Adam et al. 2007, Casale and Margaritoulis, 2010). Richardson (1999) stated that a complete study of all aspects related to nesting biology is essential for the selection and application of suitable marine turtle population conservation and management.

With the present trends and potential impacts of global warming, increased temperature can affect the sex ratio in marine turtles as well as in many other reptile species (Janzen and Paukstis 1991), as it is determined by the prevailing environmental conditions (mainly nest temperature) during the embryonic development (TSD for temperature-dependent sex determination). This means that warming temperatures could lead to a higher production of female hatchlings.

Sex determination is the initial event in which undifferentiated gonads opt for either ovarian or testicular differentiation. This process in most vertebrate species is genotypic (GSD for genotypic sex determination), leaving little scope for deviation from a balanced primary sex ratio (Zbinden et al. 2007).

In marine turtles, sex depends on the proportion of time spent at specific temperatures during the thermosensitive period (TSP), which is the middle third stage of incubation (Mrosovsky and Pieau 1991). The point at which a balanced sex ratio occurs is known as the pivotal temperature; more females result from temperatures above the pivotal temperature and more males from cooler temperatures (see Wibbels 2003 for a review).

For convenience, three major life-stages (hatchlings, juveniles, and adults) can be distinguished in marine turtles; different methods are used to investigate sex ratios at each of these stages (Casale et al. 2006). Hatchling sex ratio is obtained directly, through microscopic examination of hatchling gonads (Wood et al. 1983) sampled at nesting beaches (e.g. Yntema and Mrosovsky 1980), indirectly estimated as a function of a series of nest temperature records (e.g. Standora and Spotila 1985) or using additional variables associated with nest temperature, such as the incubation duration (e.g. Mrosovsky et al. 1999). Adults are easily differentiated because of their external sexual dimorphism, in particular, the most obvious characteristic is the large and muscular prehensile tail of adult males (Casale et al. 2005). Juvenile sex ratio is the most difficult to obtain, owing to both the at-sea sampling requirement and the absence of sexual dimorphism. Other methods for estimating sex ratio are to use blood hormonal levels (Owens et al. 1978), observation of gonads by laparoscopy (Wood et al. 1983), or necropsy of dead animals (Work 2000).

The determination of sex and hence the sex ratio of hatchlings is very significant basic information in marine turtle population dynamics (Casale et al. 2006, Zbinden et al. 2007). It should therefore be taken into account in any conservation planning of nesting beaches in order to conserve the "population's sexual structure" and act in an appropriate manner for the protection of these endangered reptiles, especially in the context of current global warming (Hawkes et al. 2009, Witt et al. 2010). Indeed, in species with TSD, the sex-determining pathway is extremely sensitive to temperature (Mrosovsky et al. 2009). The transitional range of temperature within which the complement of offspring sex shifts from $100 \%$ male to $100 \%$ female (or vice versa) is generally less than $2{ }^{\circ} \mathrm{C}$, and may be less than $1^{\circ} \mathrm{C}$ (Ewert et al. 1994), while the mean warming predicted on a scale of 100 years is $2^{\circ} \mathrm{C}$ (GIEC 2007).

Among the worlds seven marine turtle species, three species are regularly observed in the Mediterranean. The loggerhead turtle, Caretta caretta, the most common species dispersed across all marine areas, has important nesting sites in Greece, Libya, Turkey and Cyprus (Margaritoulis et al. 2003, Casale and Margaritoulis 2010). The green turtle, Chelonia mydas, is restricted to the Levantine basin of the Mediterranean, with nesting sites in Turkey, Cyprus and Syria (Kasparek et al. 2001, Casale and Margaritoulis 2010). The leatherback turtle, Dermochelys coriacea, has no nesting population at all in the Mediterranean (Lescure et al. 1989), but enters the basin in small numbers from the Atlantic ocean (Margaritoulis 1986, Casale et al. 2003, Bradai et al. 2004, Casale and Margaritoulis 2010). Investigations of the sex ratio of all three classes of loggerhead turtles (hatchlings, juveniles, and adults) have recently begun in the Mediterranean region, but the results cannot yet be considered conclusive at the regional population scale (Casale et al. 2006). The loggerhead hatchling sex ratios are estimated to be female-biased on most beaches (Godley et al. 2001, Öz et al. 2004, Zbinden et al. 2006, Witt et al. 2010).

All three marine turtle species mentioned above were reported in Libyan waters, but only the loggerhead turtle is a nesting species along the Libyan coast (Schleich 1987, Laurent et al. 1997, 1999, Hamza 2010). The importance of Libyan sandy beaches for marine turtle nesting was realized in 1995-1998 when national surveys at potential nesting beaches revealed a major rookery of loggerhead turtle nesting (Laurent et al. 1997). The results showed a substantial number of marine turtle nests laid each season, exceeding the number of nests in Cyprus and Turkey, and possibly equal to or higher than that in Greece (Laurent et al. 1997, 1999). The subsequent surveys in 2005-2008 indicated that nesting is largely concentrated mainly in four areas: the Gulf of Sirte, the region around Benghazi, some sandy beaches of Aljabal Alakhdar (Cyrenaica) and the region of Derna-Tubrok (Hamza 2010). In view of the nesting density and the large distribution range, these sites should be considered as a major Mediterranean nesting site for the loggerhead turtle.

Recalling the articles of the SPA protocol and the revised action plan on marine turtles in the Mediterranean, taking into account the new developments concerning conservation measures based on scientific groundwork, and considering the potential effects of 
global warming on future population structure and on the dynamics of these endangered species (Hawkes et al. 2009, Witt et al. 2010), the present study aimed to provide data on hatchling sex ratio estimation from five nesting beaches west of Sirte, which are among the most important nesting grounds for loggerhead turtles in Libya and potentially in the Mediterranean (Hamza 2010). Since the sex of marine turtle hatchlings cannot be assessed from external morphology and sacrificing hatchlings was not an option for ethical and conservation reasons, we used incubation duration of clutches and the mean temperatures during the middle third of the incubation period as indirect methods for predicting the sex ratios within the nests.

\section{MATERIALS AND METHODS}

The Libyan coast spans approximately $2000 \mathrm{~km}$ (Fig. 1). Most of this coast is still in pristine condition because of limited human activity and an undeveloped fishing industry compared with neighbouring countries (Laurent et al. 1997).

Generally, the nesting season in Sirte starts in late May and continues until mid-August and sometimes early September (Hamza 2010). The fieldwork was conducted during the summer months of 2009 on the beaches of Al-Ghbeba (length $5.12 \mathrm{~km}$, average width $65 \mathrm{~m}$ ), Al-Thalateen (length $5.43 \mathrm{~km}$, average width $55 \mathrm{~m}$ ), west of Al-Thalateen (length $3.45 \mathrm{~km}$, average width $35 \mathrm{~m}$ ), Shash (length $4.85 \mathrm{~km}$, average width 35 ) and Al-Arbaeen (length $8.54 \mathrm{~km}$, average width $40 \mathrm{~m})$. These beaches are located on the Gulf of Sirte, which has a total length of more than $800 \mathrm{~km}$. Nesting and hatching activity were observed over the beaches as part of the long-term monitoring undertaken by the Libyan Sea Turtle Programme (LibSTP) since 2005. Each nest was located by walking on the beach and the precise GPS position was recorded in order to locate the nest and identify its first hatchling emergence date. Sampled nest locations were chosen to fall within the mean distance from the sea line, based on same year data collected at each beach weeks prior to data logger placement. The monitored nests were protected by under-sand wire netting to deter predators (mainly red foxes, Vulpes vulpes). Nest distance from the sea was recorded from the nest location to the sea line. For the purpose of this study, incubation duration is defined as the period in days between observation of the newly laid nest and the first record of emergence, by either direct observation of hatchlings or their crawl tracks emerging from nests.

Temperatures in 14 loggerhead turtle nests were examined using a LogTag HAXO-8 electronic humidity and temperature data logger (LSTechnology, UK) from July to September 2009 on the selected beaches (when most clutches are in their thermosensitive stage for sex determination).

In order to cover the entire nesting site so that the study could be representative of the area, the data log-

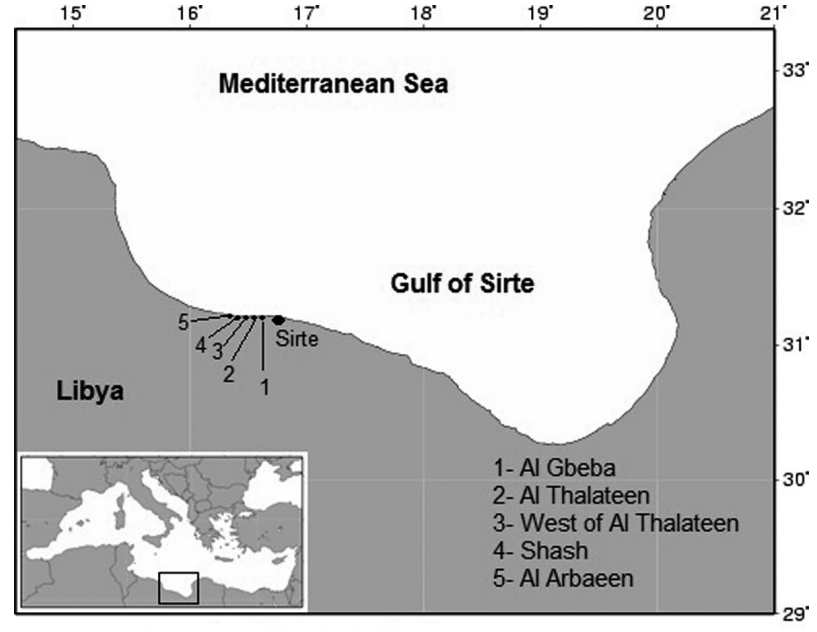

FIG. 1. - The loggerhead nesting sites on Sirte beaches (Libya).

gers were distributed to all beaches according to the nesting densities of 2009 and previous seasons at each beach (Hamza, 2010) as follows: 3 at Al-Ghbeba, 2 at Al-Thalateen, 2 at west of Al-Thalateen, 4 at Shash and 3 at Al-arbaeen. Within each nesting beach, nest sites were selected so that the data loggers were homogeneously spread along the beach length. Furthermore, the locations of studied nests were also chosen within the area of mean distance from the wave line, based on data of nests laid at the start of the same season. Due to logistical restrictions, there was a delay in 9 data logger placements, but in all cases temperature/humidity data loggers were placed into the centre of the nests before the start of the second third of the incubation period. A small hole was made adjacent to the egg chamber, without excavating the nest, 3-4 eggs were carefully removed in order to place the data logger and then they were returned to their initial positions, with the exact orientation. Temperatures and humidity at three levels (top, middle, and bottom) in two nests were also recorded. The temperatures were not initiated in one nest in Al-Ghbeba due to a malfunction of the data logger. This nest was later visited and the date of emergence was not accurately determined. Therefore, it was excluded from data analysis.

Additionally, temperature data loggers were buried adjacent to each nest (Approximately $1 \mathrm{~m}$ to the east at the same depth and the same distance from the sea) in order to study the effect of metabolic heating. All loggers were programmed to record a reading every 15 minutes.

The middle third of the incubation period was calculated on the basis of the incubation period mentioned above. Nest contents were excavated within a specific period after the first hatchling emergence, as suggested by Adam et al. (2007); nest depths were measured and data loggers were retrieved. The total number of eggs (the number of eggs laid into the nest) and the hatching success were calculated by counting unhatched eggs, dead hatchlings in eggs, dead hatchlings in nests and empty eggshells (>50\% complete) which were char- 
acterized as successful hatching. The hatching success (\%) is calculated as follows: (empty eggshells/ total number of eggs) $* 100$.

The sex ratio of hatched loggerhead turtles was estimated using two methods. The first used the mean temperature during the middle third of the incubation period, while the second used the incubation duration. The curves used for estimation of sex ratio as functions of incubation duration and temperature during the second third of the incubation duration were those of Mrosovsky et al. (2002) adapted to the field. The sex ratio curve (\% of females) as a function of the mean temperature during the second third of incubation duration was adapted to the field by adding $0.4^{\circ} \mathrm{C}$ (Mrosovsky et al. 2002), which corresponds to the difference between ambient temperature and egg temperature (Fig. 2). The sex ratio curve (\% of females) as a function of incubation duration (Mrosovsky et al. 2002) was also adapted to the field by adding 4 days, which corresponds to the interval between hatching and the emergence of hatchlings at the sand surface (Godfrey and Mrosovsky 1997) (Fig. 3). The equations of the two curves used (after corrections) were calculated and the exact values of sex ratios were derived. The choice of the study of Mrosovsky et al. (2002) is based on the fact that turtles from Greece and those of Libya are part of the same Mediterranean population and have the same geographic range. This choice is also based on the fact that pivotal temperature in marine turtles is a relatively conservative characteristic (Rees and Margaritoulis 2004, Mrosovsky et al. 2009).

\section{RESULTS}

During the 2009 nesting season, 358 nests were recorded in the study area (about $25 \mathrm{~km}$ ). The nesting density varied between 9.02 nests $/ \mathrm{km}$ at Al-Thalatheen beach to 21.65 nests $/ \mathrm{km}$ at Shash beach, with an average of 14.45 nests $/ \mathrm{km}$ at all beaches. Distances of studied nests to the wave line were found to be within the limits of nest distribution at each nesting beach during the previous nesting period of the same season (Table 1).

The information on the 13 studied nests is presented in Table 2. The information on temperature and humidity recorded in the studied nests and in adjacent sand (1
TABLE 1. - Distance from the wave line of studied nests in comparison with all recorded nests at each nesting beach.

\begin{tabular}{|c|c|c|c|}
\hline \multirow{2}{*}{ Beach } & \multirow{2}{*}{$\begin{array}{c}\text { Distance of } \\
\text { monitored nests } \\
\text { mean }\end{array}$} & \multicolumn{2}{|c|}{$\begin{array}{c}\text { Distance of other } \\
\text { nests }\end{array}$} \\
\hline & & Mean & $\mathrm{SD}$ \\
\hline Al-Ghbeba & 13.33 & 18.12 & 12.44 \\
\hline Al-Thalatheen & 12.5 & 14.78 & 8.75 \\
\hline W. Al-Thalatheen & 16.75 & 15.80 & 9.54 \\
\hline Shash & 13.25 & 16.06 & 9.15 \\
\hline Al-Arbaeen & 18.67 & 12.87 & 6.85 \\
\hline
\end{tabular}

$m$ to the west at the same depth) is presented in Tables 3 and 4 respectively.

The mean temperature of the whole incubation period (each temperature data point recorded was used) for the 13 nests ranged from $29.1^{\circ} \mathrm{C}$ to $32.1^{\circ} \mathrm{C}$. The maximum temperature increase during the incubation period was $5.3^{\circ} \mathrm{C}$ (for nest 9, minimum of $29.3^{\circ} \mathrm{C}$, maximum of $34.6^{\circ} \mathrm{C}$ ).

The mean temperature in nests during the middle third of the incubation ranged from $29^{\circ} \mathrm{C}$ (Nest 10) to $31.8^{\circ} \mathrm{C}$ (Nest 9). The maximum temperature increase during this period was $3.5^{\circ} \mathrm{C}$ (nest 9: minimum of $30.2^{\circ} \mathrm{C}$, maximum of $33.7^{\circ} \mathrm{C}$ ). The minimum temperature increase was $0.6^{\circ} \mathrm{C}$ (nest 3 : minimum of $28.9^{\circ} \mathrm{C}$, maximum of $29.5^{\circ} \mathrm{C}$ ).

The mean temperature during the incubation period increased in the middle third of the incubation period compared with the first third and continued to increase during the last third. This is not the case for the adjacent sand (control), where air temperature controls the increase and decrease in soil temperature.

Regarding humidity, it seemed that the air in the nests and adjacent sand was saturated with water. However, there was some decrease in humidity prior to emergence, which could indicate when hatching commences and the proximity of hatchling emergence. This point should be investigated further in the coming years.

As expected, beach temperatures decreased with increasing depth (Table 5). This parameter was studied in nest 13 (Data loggers in nest 4 did not function well).

Positioning temperature data loggers in both the sand and the nests allowed us to compare the temperatures at the same depth in both settings (Table 3 ). During the total incubation period, the daily mean sand temperatures were $0.2^{\circ} \mathrm{C}$ to $2.2^{\circ} \mathrm{C}$ lower than in

TABLE 2. - Information on the studied nests.

\begin{tabular}{|c|c|c|c|c|c|c|}
\hline Nest & Beach & Laying date & Start of monitoring & Clutch size & Emergence success & Incubation duration (days) \\
\hline 11 & Al-Ghbeba & 07/07 & $21 / 07$ & 69 & 85.5 & 49 \\
\hline 12 & Al-Ghbeba & $20 / 07$ & $21 / 07$ & 79 & 82.3 & 51 \\
\hline 4 & Al-Thalatheen & $17 / 07$ & $21 / 07$ & 33 & 72.7 & 51 \\
\hline 5 & Al-Thalatheen & $12 / 07$ & $21 / 07$ & 105 & 33.3 & 47 \\
\hline 3 & W.Al thalatheen & $26 / 07$ & $27 / 07$ & 45 & 82.2 & 58 \\
\hline 10 & W.Al thalatheen & $16 / 07$ & $27 / 07$ & 74 & 95.9 & 55 \\
\hline 6 & Shash & $10 / 07$ & $22 / 07$ & 86 & 81.4 & 54 \\
\hline 8 & Shash & $21 / 07$ & $29 / 07$ & 39 & 82.1 & 57 \\
\hline 2 & Shash & $13 / 07$ & $29 / 07$ & 45 & 71.1 & 52 \\
\hline 13 & Shash & $22 / 07$ & $22 / 07$ & 91 & 94.5 & 47 \\
\hline 1 & Al-Arbaeen & $01 / 08$ & $02 / 08$ & 69 & 78.2 & 50 \\
\hline 7 & Al-Arbaeen & 08/07 & $22 / 07$ & 75 & 77.3 & 55 \\
\hline 9 & Al-Arbaeen & 08/07 & $22 / 07$ & 63 & 93.7 & 52 \\
\hline
\end{tabular}


TABLE 3. - Mean temperature in study nests and adjacent sand during different incubation periods. IP, incubation period. The data logger in nest 7 stopped during the last third of the IP.

\begin{tabular}{lcccccccc}
\hline \multirow{2}{*}{ Nest } & \multicolumn{9}{c}{ In nest } & \multicolumn{4}{c}{ In sand } \\
& Total IP & First third IP & Middle third IP & Last third IP & Total IP & First third IP & Middle third IP & Last third IP \\
\hline 1 & 29.9 & 29.4 & 29.9 & 30.2 & 28.3 & 28.5 & 28.5 & 27.9 \\
2 & 29.8 & 29.1 & 29.5 & 30.3 & 29.4 & 29.2 & 29.4 & 29.5 \\
3 & 29.1 & 28.7 & 29.2 & 29.3 & 28.2 & 28.4 & 28.5 & 27.6 \\
4 & 31.2 & 30 & 31.3 & 31.8 & 30.8 & 30.3 & 31.2 & 30.9 \\
5 & 30.2 & 29.1 & 29.9 & 31 & 29.5 & 29.1 & 29.4 & 29.6 \\
6 & 30.3 & 29.1 & 29.8 & 31.2 & 29.5 & 29.2 & 29.4 & 29.6 \\
7 & 2 & 29.2 & 29.7 & 29.1 & 29.5 & 29.5 & 29.6 \\
8 & 29.9 & 29.1 & 29.9 & 30.3 & 29.4 & 29.3 & 29.8 & 30 \\
9 & 32.1 & 30.3 & 31.8 & 32.5 & 29.9 & 29.1 & 29.2 & 29.2 \\
10 & 29.5 & 28.6 & 29 & 30.3 & 29.2 & 31.1 & 30.9 & 31.4 \\
11 & 31.3 & 30 & 30.6 & 32.2 & 31.1 & 29.2 & 29.8 & 29.5 \\
12 & 30.4 & 29.2 & 30.3 & 31.5 & 29.5 & 29.1 & 29.6 & 29.4 \\
13 & 30.6 & 29.4 & 30.3 & 31.8 & 29.4 & & & \\
\hline
\end{tabular}

TABLE 4. - Mean humidity in studied nests and adjacent sand (control) during different incubation periods. IP, incubation period.

\begin{tabular}{ccccccccc}
\hline & \multicolumn{3}{c}{ In nest } & \multicolumn{3}{c}{ In sand } \\
& Total IP & First third IP & Middle third IP & Last third IP & Total IP & First third IP & Middle third IP & Last third IP \\
\hline 1 & 94.9 & 100 & 100 & 81.8 & 99.9 & 100 & 100 & 99.7 \\
2 & 94.1 & 99.8 & 100 & 87.4 & 100 & 99.8 & 100 & 100 \\
3 & 100 & 100 & 100 & 100 & 100 & 100 & 100 & 100 \\
4 & 100 & 100 & 100 & 100 & 100 & 100 & 100 & 100 \\
5 & 100 & 100 & 100 & 100 & 100 & 99,8 & 100 & 100 \\
6 & 100 & 100 & 100 & 100 & 100 & 99.8 & 100 & 100 \\
7 & 100 & 99,9 & 100 & 100 & 100 & 100 & 100 & 100 \\
8 & 100 & 100 & 100 & 100 & 100 & 100 & 100 & 100 \\
9 & 99.9 & 97.6 & 100 & 100 & 100 & 99.6 & 100 & 100 \\
10 & 100 & 100 & 100 & 100 & 100 & 100 & 100 \\
11 & 59.2 & 100 & 97.8 & 10.8 & 100 & 100 & 100 \\
12 & 85.2 & 100 & 100 & 57.1 & 100 & 100 & 100 & 100 \\
13 & 95.2 & 100 & 100 & 85.7 & 100 & 100 & 100 \\
\hline
\end{tabular}

TABLE 5. - Mean temperature $\left({ }^{\circ} \mathrm{C}\right)$ in different parts of the nest 13 during the incubation period. T, top; M, middle; B, bottom; TSP, thermosensitive period.

\begin{tabular}{lcc}
\hline \multicolumn{1}{c}{ Period } & & Mean temperature \\
\hline \multirow{2}{*}{ Incubation period } & $\mathrm{T}$ & 31.3 \\
& $\mathrm{M}$ & 30.6 \\
\multirow{3}{*}{ Before TSP } & $\mathrm{B}$ & 30.2 \\
& $\mathrm{~T}$ & 30.3 \\
TSP & $\mathrm{M}$ & 29.4 \\
& $\mathrm{~B}$ & 29.1 \\
\multirow{4}{*}{ After TSP } & $\mathrm{T}$ & 31.3 \\
& $\mathrm{M}$ & 30.3 \\
& $\mathrm{~B}$ & 30 \\
& $\mathrm{~T}$ & 32.2 \\
& $\mathrm{M}$ & 31.8 \\
\hline
\end{tabular}

loggerhead nests at the same time and depth. During the middle third of the incubation period, when sex is thought to be determined, the mean temperature difference between nest and sand was $0.48^{\circ} \mathrm{C}(\mathrm{n}=13$; $\left.-0.2-2^{\circ} \mathrm{C}\right)$.

The equation of sex ratio ( $\%$ of females) as a function of temperature is as follows (Fig. 2):

$$
\mathrm{Y}=100.06 /(1+\operatorname{Exp}(+188.78-6.37 * \mathrm{X}))
$$

where $\mathrm{Y}$ is the sex ratio and $\mathrm{X}$ is the temperature.

The equation of sex ratio ( $\%$ of females) as a function of incubation duration is as follows (Fig. 3):

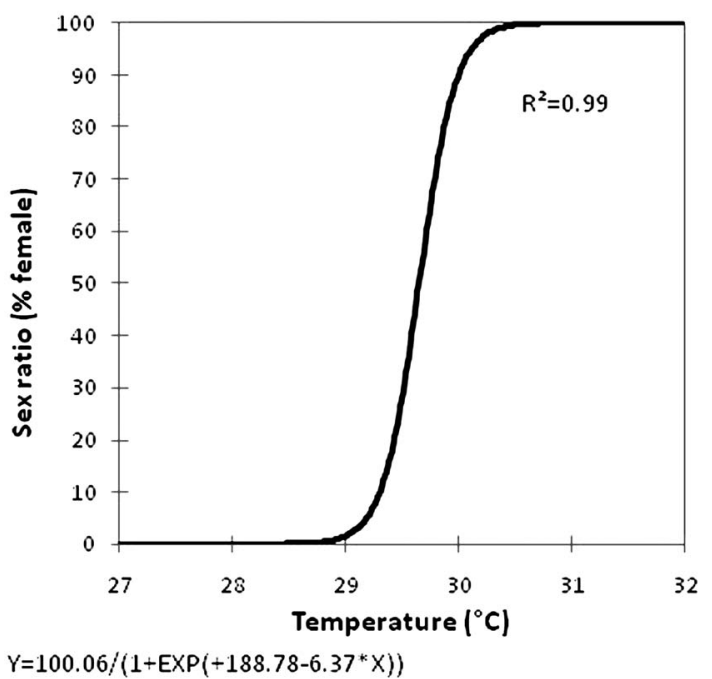

FIG. 2. - Percentage of females as a function of temperature (Derived from Mrosovsky et al. (2002) and adapted to the field).

$$
\mathrm{Y}=99.88 /(1+\operatorname{Exp}(-103.34+1.82 * \mathrm{X}))
$$

where $\mathrm{Y}$ is the sex ratio and $\mathrm{X}$ is the incubation duration.

The sex ratios of hatchlings for all nests estimated from curve equations are shown in Table 6. The mean sex ratio based on average temperature during the middle third of incubation duration $\left(\mathrm{T}^{\circ}\right)$ was $70.4 \%$ and 


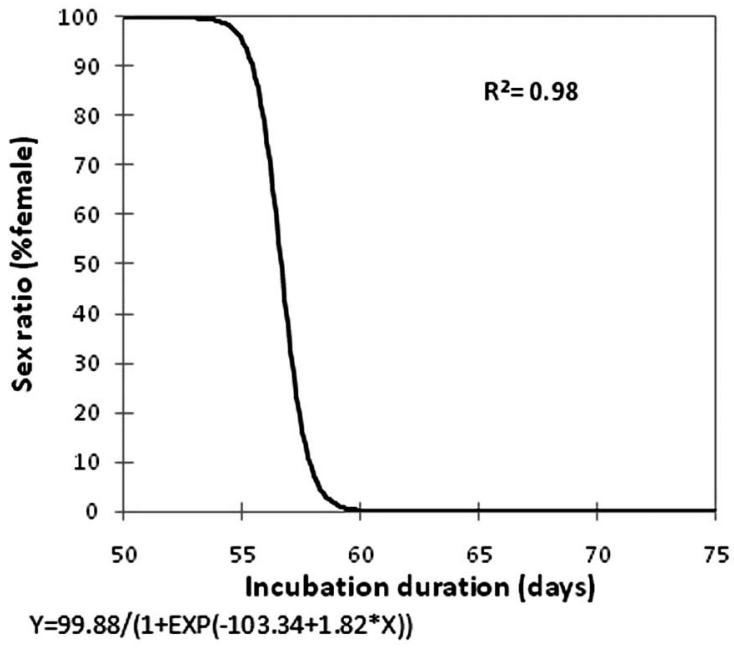

FIG. 3. - Percentage of females as a function of incubation duration (Derived from Mrosovsky et al. (2002) and adapted to the field).

the mean sex ratio based on incubation duration (ID) was $85.4 \%$.

The sex ratio ranged between $5 \%$ (with the $\mathrm{T}^{\circ}$ method) or $8 \%$ (with the ID method) and $100 \%$, but sex ratio between nests did not vary significantly (KruskalWallis test, $\mathrm{H}=17.469, P=0.133$ ).

Of the 13 nests, 11 were predicted to produce more females if the estimation was based on incubation duration. If based on temperature during the second third of incubation duration, 10 were predicted to produce more females and three were predicted to produce more males. Comparison of the two methods indicates that sex ratios are not significantly different $(\mathrm{t}=1.725841$, $\mathrm{df}=12$, $\mathrm{p}$-value $=0.110007$ ). Comparison of the two methods for each beach taken separately also shows that there is no significant difference; $p$-values of the t-test for the beaches of Al-Ghbeba, Al-Thalateen, west of Al-Thalateen, Shash and Al-Arbaeen were respectively $0.5,0.5,0.47,0.64$ and 0.23 .

Furthermore, the analysis of the results of the sex ratio estimated by the two methods shows that there was no difference among the five beaches (KruskalWallis test, $\mathrm{H}=7.154$, pvalue $=0.128$ for the $\mathrm{T}^{\circ}$ method and $\mathrm{H}=6.629$, $\mathrm{p}$-value $=0.157$ for the ID method).

Similarly, the analysis of sex ratio results for the nests laid in early July and those laid in late July showed no significant differences (Kruskal-Wallis test, $\mathrm{H}=0.021$, $\mathrm{p}$-value $=0.885$ for the $\mathrm{T}^{\circ}$ method and $\mathrm{H}=0.663$, $\mathrm{p}$-value $=0.415$ for the ID method).

\section{DISCUSSION AND CONCLUSION}

Sex ratio estimations and their biological and ecological implications are clearly a complex issue. The threats to nesting beaches are increasing and funding for conservation programmes may not be keeping pace, so it is becoming increasingly important to make informed decisions and draw up appropriate strategies (Kaska et al. 2006). Studies, knowledge and monitoring of hatchling's sex ratios should be a part of this process.

The results of the present study were in agreement with the common pattern of loggerhead marine turtle sex ratios in the Mediterranean region, which is female-dominated (Hanson et al. 1998, Kaska et al. 1998, 2006, Godley et al. 2001, Öz et al. 2004, Rees and Margaritoulis 2004, Witt et al. 2010, Rees et al. 2013). Although methodologies and timescales of studies vary, this tendency of female production is accepted to be globally predominant (Wibbels 2003). However, the sex- ratio estimated (\% females) in this study (70.4\% and $85.4 \%$ of females) should be considered as maximum because the few nests laid during June, which were not studied because the field sites were inaccessible during that month, had a cooler temperature regime than July when most clutches are laid. Therefore, it would seem wise to pay particular attention to the few possible male-producing clutches laid at the start of the season.

The measurements of temperature at the different parts of the nest (top, middle and bottom) allowed us to claim that the mean temperature in the central part of the nest is representative of the whole nest sections. Recording only central parts of the nests therefore allowed us to save more data loggers to be used at other nests and yielded the best estimation of sex ratios.

TABLE 6. - Information on nests, incubation duration and temperature data with the estimated sex ratio (\% $\%$ ). ID, incubation duration.

\begin{tabular}{|c|c|c|c|c|c|c|c|}
\hline Nest & $\begin{array}{l}\text { Clutch } \\
\text { size }\end{array}$ & $\begin{array}{l}\text { Emergence } \\
\text { success }\end{array}$ & $\begin{array}{l}\text { Distance from } \\
\text { sea }(\mathrm{m})\end{array}$ & ID & $\mathrm{T}^{\circ}$ (Middle third ID) & $\begin{array}{l}\text { Sex ratio }(\%+) \\
\text { from ID }\end{array}$ & $\begin{array}{l}\text { Sex ratio }(\% \text { \% }) \\
\text { from } \mathrm{T}^{\circ}\end{array}$ \\
\hline 1 & 69 & 78.2 & 16.5 & 50 & 29.9 & 100 & 83 \\
\hline 2 & 45 & 71.1 & 23.5 & 52 & 29.5 & 100 & 28 \\
\hline 3 & 45 & 82.2 & 23 & 58 & 29.2 & 8 & 5 \\
\hline 4 & 33 & 72.7 & 10 & 51 & 31.3 & 100 & 100 \\
\hline 5 & 105 & 33.3 & 15 & 47 & 29.9 & 100 & 83 \\
\hline 6 & 86 & 81.4 & 8.5 & 54 & 29.8 & 99 & 72 \\
\hline 7 & 75 & 77.3 & 8.5 & 55 & 29.7 & 95 & 58 \\
\hline 8 & 39 & 82.1 & 10 & 57 & 29.9 & 34 & 83 \\
\hline 9 & 63 & 93.7 & 31 & 52 & 31.8 & 100 & 100 \\
\hline 10 & 74 & 95.9 & 9.5 & 56 & 29.2 & 76 & 5 \\
\hline 11 & 69 & 85.5 & 9.5 & 49 & 30.6 & 100 & 100 \\
\hline 12 & 79 & 82.3 & 12.5 & 51 & 30.3 & 100 & 98 \\
\hline 13 & 91 & 94.5 & 11 & 47 & 30.3 & 100 & 98 \\
\hline Mean & 67.2 & 79.2 & & 52.2 & & 85.4 & 70.4 \\
\hline
\end{tabular}


However, this finding might be not applicable to other Mediterranean nesting sites with different physical and biological characteristics (e.g. soil type, humidity and vegetation cover).

In this study, the daily mean temperature of sand during the entire incubation period was $0.48^{\circ} \mathrm{C}$ (range: $-0.2-2.2$ ), which is lower than the corresponding mean in loggerhead nests at the same depths. This figure is lower than those of northern Cyprus and Turkey (range: 1.1-1.9 ${ }^{\circ} \mathrm{C}$ ) (Kaska et al. 1998), Zakynthos (Greece) (mean: $0.6^{\circ} \mathrm{C}, \mathrm{CI}$ : 0.25 ) (Zbinden et al. 2006) and Tunisia (mean: $2^{\circ} \mathrm{C}$, range:1-2.9) (Jribi et al. 2012). Taking into consideration that we measured the nest temperature at the centre of the clutch and that it has been shown, however, that temperature in loggerhead clutches is not evenly distributed (Godfrey et al. 1997, Hanson et al. 1998, Kaska et al. 1998, Booth and Astill 2001, Houghton and Hays 2001) and that the amount of metabolic heating is higher in the centre than at the sides of the clutch (Godfrey et al. 1997, Booth and Astill 2001), our results are likely to have overestimated the amount of metabolic heating experienced by the average egg. This potential bias is not likely to affect the sex ratio as this heat increase is negligible (Zbinden et al. 2006). Results of our study on an area with a large nesting potential support the conclusion of Zbinden et al. (2006) with loggerhead clutches of Zakynthos, which is the largest among Mediterranean populations (Margaritoulis et al. 2003), that metabolic heat production has no significant feminizing effect on Mediterranean loggerheads.

Although a female-biased primary sex ratio for hatchling production was found in this study by two methods, the temperature method was more accurate than the incubation duration method, because the latter was based on the relationship between incubation duration and the temperature during the entire development period. Therefore, it is less accurate, as it is indirect and based not only on the middle third of the incubation duration. The other thirds may confound results in case of within-clutch heterogeneous temperature regimes. More studies would be needed in the next few years to investigate any inter-annual differences in sex ratio of hatchlings occurring at these nesting beaches.

The coverage of other nesting sites in Libya, which might have different local climatic conditions, is necessary and the factors that may alter the sex ratio, such as inundation and predation, should be considered and further assessed. Indeed, nest inundation has been shown to increase incubation duration and has been suggested to possibly play a significant role in masculinization of turtle hatchlings (Rees and Margaritoulis 2004). Data analyses should take incubation duration of inundated nests into account. LibSTP nest management activities aim to reduce the number of nests inundated by the sea, as this can be an important cause of nest mortality. Nests are relocated away from the dangerous surf zone and installed in zones which are thermally inclined to the production of female turtles.
Thus, the number of male hatchlings may be reduced slightly but the overall number of hatchlings is greatly increased (Rees and Margaritoulis 2004).

Nest predation is also known to have effects on the sex ratio of hatchlings that emerge from the nest and reach the sea. The longer the incubation period, the greater the chances of nests being predated. Kaska et al. (2006) stated that smell and activities of the first group(s) of hatchlings may provide clues for predators about the location of a nest, and those emerging towards the end of the hatching duration are threatened most. Nest predation is a major threat at Sirte beaches (Hamza and Elghmati 2006), especially when conservation practices are not fully in place, and it also has an important indirect effect on the loggerhead sex ratios.

It was planned to extend the current study in 2010 to include important nesting beaches of the Misuratah province, but during of the conflict in Libya in 2011 it was not possible to retrieve the data loggers from Misuratah office or to conduct any field work because of the security situation and the suspicion of the risk of landmines in the study area. Until this threat is cleared any future fieldwork is not feasible.

The civil conflicts can seriously halt conservation efforts for marine turtles in Libya unless the international community help the new authorities to conduct actions in the field and to restructure the conservation sector of the country to safeguard the remains of the best marine turtle nesting, wintering and feeding habitats in the Mediterranean.

\section{ACKNOWLEDGEMENTS}

The authors would like to thank the director and staff of the Environment General Authority (EGA) in Libya. Also, our sincere gratitude goes to the UNEPMAPRAC/SPA director and staff for support and staff time. We also thank the team of the EGA Sirte branch, officials and the private sector, who did their best to achieve this conservation programme. All thanks are also addressed to the two anonymous reviewers for detailed corrections and constructive comments and to Rachel Franceour for the revision of the English.

\section{REFERENCES}

Adam V., Tur C., Rees A.F., Tomas J. 2007. Emergence pattern of loggerhead turtle (Caretta caretta) hatchlings from Kyparissia bay, Greece. Mar. Biol. 151: 1743-1749.

Booth D.T., Astill K. 2001. Temperature variation within and between nests of the green sea turtle, Chelonia mydas (Chelonia: Cheloniidae) on Heron Island, Great Barrier Reef. Aust. J. Zool. 49: 71-84.

Bradai M.N., Nicolosi P., Casale P., Jribi I., Turchetto M., El Abed A. 2004. The presence of leatherback turtles in the central Mediterranean area: data from Italy and Tunisia. Biol. Mar. Med. 11(2): 750-753.

Casale P., Nicolosi P., Freggi D., Turchetto M., Argano R. 2003. Leatherback turtles (Dermochelys coriacea) in Italy and in the Mediterranean basin. Herpetol. J. 13(3): 135-139.

Casale P., Freggi D., Basso R., Argano R. 2005. Size at male maturity, sexing methods and adult sex ratio in loggerhead turtles (Caretta caretta) from Italian waters investigated through tail 
measurements Herpetol. $J .15: 145-148$

Casale P., Lazar B., Pont S., Tomas J., Zizzo N., Alegre F., Badillo J., Di Summa A., Freggi D., Lackovic G., Raga J.A, Rositani L., Tvrtkovic N. 2006. Sex ratios of juvenile loggerhead sea turtles Caretta caretta in the Mediterranean Sea. Mar. Ecol. Prog. Ser. 324: 281-285

Casale P., Margaritoulis D. (eds) 2010. Sea turtles in the Mediterranean: Distribution, threats and conservation priorities. Gland, Switzerland, IUCN Press, 294 pp.

Ewert M.A., Jackson D.R., Nelson C.E. (1994) Patterns of temperature-dependent sex determination in turtles. J. Exp. Zool. 270 : $3-15$

GIEC. 2007. Bilan 2007 des changements climatiques. Contribution des Groupes de travail I, II et III au quatrième Rapport d'évaluation du Groupe d'experts intergouvernemental sur l'évolution du climat [Équipe de rédaction principale, Pachauri, R.K. et Reisinger, A. GIEC, Genève, Suisse, ..., 103 pp.].

Godfrey M.H., Mrosovsky N. 1997. Estimating the time between hatching of sea turtles and their emergence from the nest. Chel. Conserv. Biol. 2: 581-585.

Godfrey M.H., Barreto R., Mrosovsky N. 1997. Metabolically generated heat of developing eggs and its potential effect on sex ratio of sea turtle hatchlings. J. Herpetol. 31: 616-619.

Godley B.J., Broderick A.C., Mrosovsky N. 2001. Estimating hatchling sex ratios of loggerhead turtles in Cyprus from incubation durations. Mar. Ecol. Prog. Ser. 210:195-201.

Hamza A. 2010. Libya. In: Casale P., Margaritoulis D. (eds), Sea turtles in the Mediterranean: Distribution, threats and conservation priorities. Gland, Switzerland, IUCN Press, pp. 157-170.

Hamza A., El Ghmati H. 2006. Conservation of Marine Turtles nesting at three sites West of Sirte, Libya. Final report. The Regional Activity Centre for Specially Protected Areas (UNEPMAP-RAC/SPA), Tunis. 35 pp.

Hanson J., Wibbels T., Martin R.E. 1998. Predicted female bias in sex ratios of hatchling loggerhead sea turtles from a Florida nesting beach. Can. J. Zool. 76: 1850-1861.

Hawkes, L.A., Broderick A.C., Godfrey M.H., Godley B.J. 2009. Climate change and marine turtles. Endang. Species Res. 7: 137-154.

Houghton, J.D.R., Hays, G.C. 2001. Asynchronous emergence by loggerhead turtle Caretta caretta hatchlings. Naturwissenschaften 88: 133-136.

Janzen F.J, Paukstis G.L. 1991. Environmental sex determination in reptiles: ecology, evolution, and experimental design. Q. Rev. Biol. 66: 149-179.

Jribi I., Ben Hassine S., Bradai M.N., Bouain A. 2012. Estimating hatchling sex ratios of loggerhead turtles from incubation duration and nest temperatures at Kuriat island, Tunisia. In: Bradai M.N., Casale P. (eds), Proceedings of the Third Mediterranean Conference on Marine Turtles, Barcelona Convention - Bern convention - Bonn Convention (CMS). Tunis, Tunisia, pp. 82-84.

Kasparek M., Godley B.J., Broderick A.C. 2001. Nesting of the Green Turtle, Chelonia mydas, in the Mediterranean: a review of status and conservation needs. Zool. Middle East 24: 45-74.

Kaska Y., Downier R., Tippett R., Furness R.W. 1998. Natural temperature regimes for Loggerhead and Green turtle nests in the Eastern Mediterranean. Can. J. Zool. 76: 723-729.

Kaska Y., Ilgaz Ç., Özdemir A., Baskale E., TurkozanO., Baran I., Stachozitsch M. 2006. Sex ratio estimations of loggerhead sea turtle hatchlings by histological examination and nest temperatures at Fethiye beach, Turkey. Naturwissenschaften 93: 338-343.

Laurent L., Bradai M.N., Haddoud D.A., El Gomati H.M. 1997. Assessment of sea turtle nesting activity in Libya. Mar. Turtle News 76: 2-6.

Laurent L., Bradai M.N., Haddoud D., El Gomati H.M., Hamza A. 1999. Marine turtle nesting activity assessment on Libyan coasts. Phase 3: Survey of the coast to the west of Misratah. Joint Project of: Marine Biology Research Centre (Tajura, Libya), MEDASSET, RAC/SPA (MAP-UNEP), TCEP (Tripoli), WWF International Mediterranean Programme. 47 pp.

Lescure J., Delaugerre M., Laurent L. 1989. La nidification de la tortue luth, Dermochelys coriacea (Vandelli, 1761) en Mediterranée. Bul. Soc. Herpétol. France. 50: 9-18.

Lutcavage M.E., Plotkin P., Witherington B. and Lutz P.L. 1997.
Human Impacts on sea Turtle Survival. In: Lutz J.A., Musick J.A. (eds), The biology of sea turtles. CRC Press, Boca Raton, Florida, USA, pp. 387-411.

Margaritoulis D. 1986. Captures and strandings of the leatherback sea turtle, Dermochelys coriacea, in Greece (1982-1984). J. Herpetol. 20(3): 471-474.

Margaritoulis D., Argano R., BARAN I., Bentivegna F., Bradai M. N., Caminas J. A., Casale P., De Metrio G., Demetropoulos A., Gerosa G., Godley B.J., Haddoud D.A., Houghton J., Laurent L., Lazar B. 2003. Loggerhead turtles in the Mediterranean Sea: Present knowledge and conservation perspectives. In: Bolten A.B., Witherington B.E. (eds), Loggerhead Sea Turtles. Smithsonian Books, Washington D.C., pp. 175-198.

Mrosovsky N., Pieau C. 1991. Transitional range of temperature, pivotal temperatures and thermosensitive stages for sex determination in reptiles. Amphibia-Reptilia 12: 169-179.

Mrosovsky N., Baptistotte C., Godfrey M.H. 1999. Validation of incubation duration as an index of the sex ratio of hatchling sea turtles. Can. J. Zool. 77: 831-835.

Mrosovsky N., Kamel S., Rees A.F., Margaritoulis D. 2002. Pivotal temperature for loggerhead turtles (Caretta caretta) from Kyparissia Bay, Greece. Can. J. Zool. 80: 2118-2124.

Mrosovsky N., Kamel S.J., Diez C.E., Van Dam R.P. 2009. Methods of estimating natural sex ratios of sea turtles from incubation temperatures and laboratory data. Endang. Species. Res. 8 147-155.

Owens D.W., Hendrickson J.R, Lance V., Callard I.P. 1978. A technique for determining sex of immature Chelonia mydas using a radioimmunoassay. Herpetologica 34: 270-273.

Öz M., Erdogan A., Kaska Y., Düsen S., Aslan A., Sert H., Yavuz M., Tunç M. R. 2004. Nest temperatures and sex-ratio estimates of loggerhead turtles at Patara beach on the southwestern coast of Turkey. Can. J. Zool. 82: 94-101.

Rees AF, Margaritoulis D. 2004. Beach temperatures, incubation durations and estimated hatchling sex ratio for loggerhead sea turtle nests in southern Kyparissia Bay, Greece. Testudo 6 : 23-36.

Rees A.F., Margaritoulis D., Newman R., Riggall T.E., Tsaros P., Zbinden J.A., Godley B.J. 2013. Ecology of loggerhead marine turtles Caretta caretta in a neritic foraging habitat: movements, sex ratios and growth rates. Mar. Biol. 160: 519-529.

Richardson J.I. 1999. Priorities for studies of reproduction and nest biology. In: Eckert KL, Bjorndal KA, Abreu-Grobois FA, Donnelly M (eds), Research and management techniques for the conservation of sea turtles. IUCN/SSC marine turtle specialist group publication no. 4, pp. 9-11.

Schleich H. 1987. Contributions to the herpetology of Kouf National Park (NE-Libya) and adjacent areas. Spixiana 10(1): 37-80.

Wibbels T. 2003. Critical approaches to sex determination in sea turtles. In: Lutz P.L., Musick J.A., Wyneken J. (eds), The biology of sea turtles, Vol II. CRC Press, Boca Raton, FL, pp 103-134.

Witt M.J., Hawkes L.A., Godfrey M.H., Godley B.J., Broderick A.C. 2010. Predicting the impacts of climate change on a globally distributed species: the case of the loggerhead turtle. J. Exp. Biol. 213: 901-911.

Wood J.R., Wood F.E., Critchley K.H., Wildt D.E., Bush M. 1983. Laparoscopy of the green sea turtle, Chelonia mydas. J. Herpetol. 6: 323-327.

Work T.M. 2000. Sea turtle necropsy manual for biologists in remote refuges. US Geological Survey, National Wildlife Health Center, Hawaii Field Station, Honolulu, HI

Yntema C. L., Mrosovsky N. 1980. Sexual differentiation in hatchling loggerheads (Caretta caretta) incubated at different controlled temperatures. Herpetologica 36(1): 33-36.

Zbinden J.A., Margaritoulis D., Arlettaz R. 2006. Metabolic heating in Mediterranean loggerhead sea turtle clutches. J. Exp. Mar Biol. Ecol. 334: 151-157.

Zbinden J.A, Davy C., Margaritoulis D., Arlettaz R. 2007. Large spatial variation and female bias in the estimated sex ratio of loggerhead sea turtle hatchlings of a Mediterranean rookery. Endang. Species Res. 3: 305-312.

Scient. ed: D. Oro.

Received March 25, 2013. Accepted September 17, 2013.

Published online October 28, 2013. 